\title{
HER2/Neu Positive by Immunohistochemistry Less than 1 Percent
}

National Cancer Institute

\section{Source}

National Cancer Institute. HER2/Neu Positive by Immunohistochemistry Less than 1

Percent. NCI Thesaurus. Code C141493.

An immunohistochemical staining finding indicating that less than 1 percent of the cells in a tissue sample are expressing receptor tyrosine-protein kinase erbB-2. 